\title{
The Impact of Animal Logging on Residual Trees in Mixed Fir and Spruce Stands
}

\author{
Jelena Knežević ${ }^{1 *}$, Safet Gurda ${ }^{1}$, Jusuf Musić ${ }^{1}$, Velid Halilović ${ }^{1}$, Dževada Sokolović ${ }^{1}$, Muhamed Bajrić ${ }^{1}$
}

(1) University of Sarajevo, Faculty of Forestry, Zagrebačka 20, BA-71000 Sarajevo, Bosnia and Herzegovina

* Correspondence: e-mail: j.knezevic@sfsa.unsa.ba
Citation: KNEŽEVIĆ J, GURDA S, MUSIĆ J, HALILOVIĆ V, SOKOLOVIĆ DŽ, BAJRIĆ M 2018 The Impact of Animal Logging on Residual Trees in Mixed Fir and Spruce Stands. South-east Eur for 9 (2): 107114. DOI: https://doi.org/10.15177/ seefor.18-16

Received: 18 Oct 2018; Revised: 29 Nov 2018; Accepted: 6 Dec 2018; Published online: 22 Dec 2018

\begin{abstract}
Background and Purpose: Logging is an example of the strongest human influence on forest environment because it causes damages to the forest soil and residual trees. The damages that occur during logging are more frequent in the skidding phase compared to the felling and processing phase.

Material and Methods: The research was conducted in mixed stands of fir and spruce in the area of eastern Bosnia and Herzegovina. Felling was conducted by chainsaw and extraction by animals, i.e. by two oxen. The following data were collected: tree species, diameter at breast height, pre-bunching zone (0-30 m or 30-60 m), presence of damages, presence of old damages, number of damages, type of damage, damage position and the size of damage.

Results: Damages were recorded on 3.32\% of residual trees. The average number of damages per damaged tree was 1.08 . The same percentage share of damages was recorded on butt end and root collar (38.46\%), while damages on root have a share of $23.08 \%$. Stem damages were not recorded. The most common type of damage was debarked tree (61.54\%), then squashed bark $(23.08 \%)$ and debarked and damaged tree $(15.38 \%)$. It was recorded that the size of damages varied between 60 and $570 \mathrm{~cm}^{2}$. The average size of damage was $222.54 \mathrm{~cm}^{2}$. Statistical analysis using $\chi^{2}$ test showed significant difference in the proportion of damaged trees among different pre-bunching methods, and did not show significant difference in the proportion of damaged trees between different pre-bunching zones.

Conclusions: It can be assumed that oxen logging causes insignificant damages to residual trees. The results of research will be used as a basis for future studies of residual trees' damaging during wood skidding.
\end{abstract}

Keywords: animal logging, oxen, damages, mixed fir and spruce stands

\section{INTRODUCTION}

Logging is an example of the strongest human influence on forest environment [1] because it causes damages to the forest soil and residual trees [2]. Tree felling and processing, as well as skidding of wood assortments, are the main phases of logging from the aspect of the extent of damage to stands and forest soil [3]. Damages to the forest ecosystem occur during felling and skidding operations, regardless of the technical means used in this process [1]. The problem of forest damages has become more and more important with the introduction of heavy mechanization in the phase of wood skidding and with the skidding of larger loads in the function of increasing productivity and economy of work [4].

Stand damaging depends on a series of different factors: work method, type of the machine used, machine characteristics and the manner of use, terrain and stand characteristics, and the relation of all participants in forestry production to forestry work and the forest itself [5]. The extent of damages is closely related to the adaptation of methods, instrumentality and organization of work to specific working conditions. In such a way, the size of damage increases with the power of the machine, the mechanization of work and larger lengths of skidded assortment [3]. 
Damages that occur during logging are more frequent in the skidding phase compared to the felling and processing phase. Tavankar et al. [6] found that percentage share of damages caused by a skidding operation with Timberjack $450 \mathrm{C}$ tractor was about $73 \%$, while damages caused by felling operations with chainsaw amounted to $27 \%$. According to Martinić [3], wood skidding is a more common cause of tree damaging compared to the felling and processing of wood during thinning operations in young stands.

The largest damages to residual trees in the wood skidding phase are caused by tractors due to constant contact with the soil and movements per stand [3]. Zahirović et al. [7] found that the percentage share of damaged residual trees during tree felling with chainsaw and skidding with tractor was 35\%.

The production of wood assortments on the territory of Bosnia and Herzegovina is partially mechanized. The main instruments of work in the skidding phase are tractors, primarily special forest tractors-skidders. Wood skidding by animals (horses and oxen) is also present [8]. Until the end of World War II in Bosnia and Herzegovina's forestry manual tools were used in the wood felling and processing phase, and animal skidding, waterways, chutes and tackles in the wood skidding phase. Technical roundwood was skidded by horses, and stacked wood (traditional one-meter long fuelwood) was skidded or carried out by horses as well. The work was done by unqualified workers organized into larger groups (about 10 workers) $[9,10]$. The necessity of introducing more complex mechanization in the phase of wood pre-bunching and skidding in Bosnia and Herzegovina occurred because of more and more expensive animal work and smaller offer of private horses [11]. In addition to the above-mentioned reasons, for the replacement of manual labor and animal labor in forestry production, the following reasons were also mentioned: outdoor work, significant influence of meteorological conditions on working procedures, decisive influence of soil conditions on work, difficult and hazardous work within deadlines limited by time and technology due to biological and other conditions, and others [5]. A portion of harvestable area is usually inaccessible for skidding operations due to uneven and steep terrain. The animal skidding system is commonly applied in small cut-block areas and on uneven slope areas up to slopes of $50 \%$, where limited timber volumes are available for transporting [12].

Animal skidding is the most rational skidding method in protected areas where low felling intensity is used and where there are no skid trails [13]. The integration of horse bunching with tractor skidding is a cost-effective solution for small wood extraction in steep terrain and in protected conservation areas. The result is a reduction in harvesting costs and skid trail density [14].

During animal skidding, products are typically transported along a common, designated skid-trail or the shortest path [12]. Steep terrains $(>40 \%)$, terrain with soft soil (soil capacity $<40 \mathrm{kPa}$ ) and uphill skidding (>8\%) should be avoided [13]. It is recommended that horse skidding be applied at shorter distances, up to $250 \mathrm{~m}$ [15]. Magagnotti and Spinelli [14] notify that horse skidding is the cheapest alternative if the total extraction distance is shorter than $200 \mathrm{~m}$.

According to Malatinszky and Fiscor [16], 26\% of Forest Districts in Hungary apply animal logging regularly, using exclusively horses. Borz and Ciobanu [17] notify that tree felling using chainsaws followed by horse logging is a practice conducted in Romania, mostly applied in very young and dense stands where thinning operations are done. Non-mechanized wood extraction was used in $60 \%$ of forest operations and skidding in $35 \%$ of the cases in mountain areas of Bulgaria [18]. Toms et al. [19] report that animal logging is used in Alabama on small tracts, tracts with low timber volumes and harvests which use selective thinning. Verani and Sperandio [20] notify that the use of animals for hauling (mules and oxen) is still quite frequent in coppice harvesting in Southern Italy.

There is only light residual stand damage and soil compaction when using horse skidding [21]. In addition to decreasing the damages to residual trees during horse skidding, the density of the secondary forest communication network is also decreased [22]. Horse skidding of roundwood and hauling of one-meter long fuelwood caused twice less damages to residual trees in comparison to other skidding methods (adapted ZETOR 6945 tractor, adapted TORPEDO TD 75064 tractor) [3]. According to Martinić [3], skidding and hauling of wood by horses caused damages to $1.9 \%$ residual trees or every 52 nd tree, which is statistically less significant in comparison to other skidding methods. Ficklin et al. [23] found that only $7 \%$ of residual trees of $>5$ " $(\approx 12.7$ $\mathrm{cm}$ ) diameter at the breast height were damaged by mule logging system in oak and pine stands (Quercus velutina Lain., Quercus alba L. i Pinus echinata Mill.), and 22\% of residual trees were damaged by the skidder system.

Also, damages to regeneration when using animal (mule) logging method were significantly lower than when using the mechanized logging method by Timberjack C450 skidder [24]. Reduction in carbon emissions due to the absence of fossil fuel is another advantage of animal use in wood extraction [21].

Skidder logging causes higher soil compaction and lower soil porosity in comparison to animal skidding (mule skidding). Skidder compact both the depth of $0-10 \mathrm{~cm}$ and $10-20 \mathrm{~cm}$, although mules mostly compact the top layer of the soil. Skidder disturbs larger area than mules during the extraction of the same wood volume [25].

Dudek and Sosnowski [26] explored the influence of different skidding technologies on tree damages in mountain area of Poland and found that two-horse skidding was the most environmentally friendly technology. Next were Larix 3T cable winch, agricultural MTZ 82 tractor, and a specialized skidder-type LKT 80 forest tractor.

Considering that animals are used for pre-bunching and skidding of the one part of felled wood in Bosnia and Herzegovina the aim of the research was to determine damages to residual trees in stands during oxen skidding. Horse is the most common and the most appropriate animal used for wood logging because of the best use of pulling force in accordance with its weight. Furthermore, it is able to increase the pulling force in a very short period of time, which is very important for wood logging. Horses are faster 
in comparison to oxen, but their purchase price, as well as feeding and maintance costs are greater. Oxen are more calm and secure during wood logging. Nontheless, because of the working method, front side of load is partially raised from the ground whereby traction resistance decreases, and load colletcs less amount of dirt, which is very important for processing in a sawmill.

\section{MATERIALS AND METHODS}

The research was conducted in eastern Bosnia and Herzegovina, in the area managed by Public Forest Enterprise "Šume Republike Srpske" a.d. Sokolac, Forest Management "Jahorina" Pale. The research object was Compartment 64, Forest Unit "Jahorina". Compartment area amounts to 86.41 ha, with altitude in the compartment ranging from 1360 to $1472 \mathrm{~m}$. Average terrain slope is up to $15^{\circ}$ with southeastern exposure. The compartment belongs to "High forest of fir and spruce or spruce on limestone soils" forest type. The share of species in the mixture is as follows: fir $37.09 \%$, spruce $53.26 \%$, beech $5.98 \%$, and other broadleaved species $3.67 \%$. The marking of trees for felling was conducted in 2016 . The volume of marked trees was $2,746.19 \mathrm{~m}^{3}$. The intensity of felling for coniferous and broadleaved trees was $10.26 \%$.

Tree felling and extraction of wood assortments was carried out during 2017. Felling and processing were conducted by using a chainsaw. The extraction of wood assortments to the landing on the truck road was carried out by animals, i.e. by two oxen. Assortment processing method was performed. In earlier planning period wood extraction was carried out by animals and tractors as well, which is the reason why tractor skidding trails exist in the compartment. Animal paths and tractor skidding trails were used for skidding wood assortments from felling to landing on the truck road. Wood assortments were prebunched by oxen via animal paths from the felling site to the tractor skidding trail and then skidded by oxen via tractor skidding trail to the landing on the truck road. The slope of the tractor skidding trails used for animal skidding was less than $5 \%$. The pre-bunching phase includes working operations of load forming and hauling of formed load to the tractor skidding trail, and the skidding phase includes wood skidding via tractor skidding trail to the landing on the truck road.

Damages to residual trees which occurred during animal logging were observed immediately after wood extraction, in August 2017. Only the damages which occurred during wood extraction were observed, while damages occurred during felling and processing were not the subject of analysis. Four stripe shape sample plots were set up in the compartment. Sample plots were set up in vertical direction to the central, longest tractor skidding trail. Sample plot 1 and sample plot 2 were located on the left side and on the right side of the tractor skidding trail respectively, at the distance of $500 \mathrm{~m}$ from the landing on the truck road. Sample plot 3 and sample plot 4 were located on the left side and on the right side of the tractor skidding trail respectively, at the distance of $100 \mathrm{~m}$ from the landing on the truck road with the aim of identifying skidding frequency influence on damage to residual trees. Sample plots were divided into two zones, with an area of $900 \mathrm{~m}^{2}$ each. The first zone of every sample plot was set up at a distance of 0-30 $\mathrm{m}$ from the skidding trail, and the second zone at a distance of 30-60 $\mathrm{m}$ from the skidding trail. The zone width was $30 \mathrm{~m}$ (Figure 1).

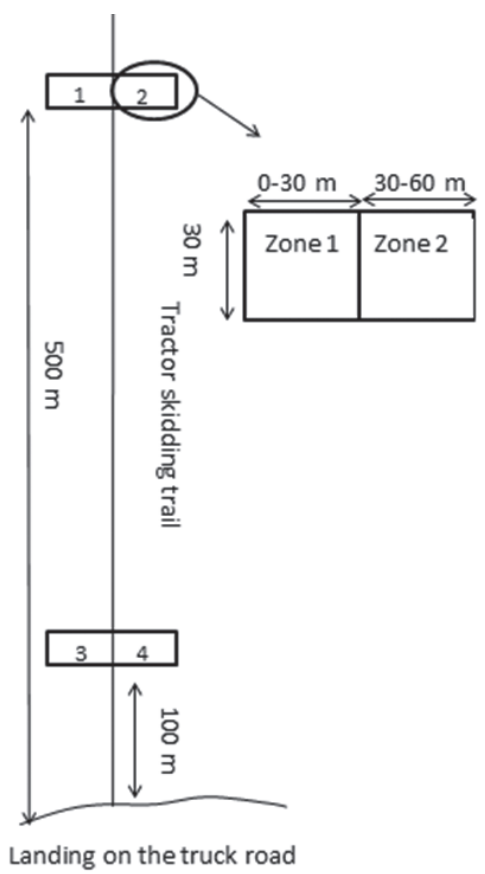

FIGURE 1. Schematic layout of sample plots.

Tree damages were determined using methodology applied by other authors [1, 3, 27-31].

At every sample plot, trees belonging to the sample were marked and recorded. Marginal trees were alternately taken and omitted from the sample. After the sample plots were set up, a detailed review of trees was conducted. Review included trees above taxation limit of $5 \mathrm{~cm}$. For every tree belonging to the sample the following data were collected: tree species, diameter at breast height, prebunching zone (0-30 m or 30-60 m), presence of damages, presence of old damages, number of damages, type of damage, damage position, and the size of damage.

Damages were classified as: squashed bark, debarked tree, and debarked and damaged tree. Squashed bark is determined as a damage to the bark with invisible zone of cambium, and debarked tree is determined as a damage with visible zone of cambium [29]. Damages were classified according to the position of the damage as: stem damage, butt end damage, root collar damage, and root damage. To determine the position of tree damage a classification created by Meng [32] was used (Figure 2). 


\author{
1 - Stem \\ 2 - Butt end \\ 3 - Root collar \\ 4 - Root \\ Source: (Meng (1978)
}

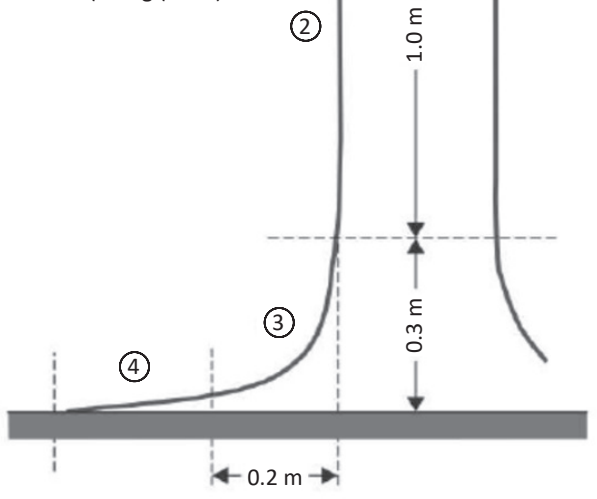

FIGURE 2. Classification of the position of tree damage.

Lengths were measured with a measuring tape, considering the terrain slope. The dimensions of damages were measured with a ruler in millimeters. The longest length and width, and the respective diameter in dependence of damage shape, were measured, and based on the measured values the damage area was calculated. Damages were classified into 4 groups according to damage size: $<25 \mathrm{~cm}^{2}, 25-100 \mathrm{~cm}^{2}, 100-200 \mathrm{~cm}^{2}$ and $>200 \mathrm{~cm}^{2}$ [30]. The damage position was determined by using a measuring tape, measuring the distance between the middle of the damage and the ground.

The following pre-bunching methods were determined at sample plots: flat terrain pre-bunching, downhill prebunching and uphill pre-bunching (Table 1).

TABLE 1. Pre-bunching method at the sample plot.

\begin{tabular}{|c|c|c|}
\hline Sample plot & Pre-bunching zone & Pre-bunching method \\
\hline \multirow{2}{*}{1} & $0-30 \mathrm{~m}$ & \multirow{2}{*}{$\begin{array}{c}\text { Uphill } \\
\text { pre-bunching }\end{array}$} \\
\hline & $30-60 \mathrm{~m}$ & \\
\hline \multirow{2}{*}{2} & $0-30 \mathrm{~m}$ & \multirow{2}{*}{$\begin{array}{c}\text { Pre-bunching on flat } \\
\text { terrain }\end{array}$} \\
\hline & $30-60 \mathrm{~m}$ & \\
\hline \multirow{2}{*}{3} & $0-30 \mathrm{~m}$ & \multirow{2}{*}{$\begin{array}{l}\text { Pre-bunching on flat } \\
\text { terrain }\end{array}$} \\
\hline & $30-60 \mathrm{~m}$ & \\
\hline \multirow{2}{*}{4} & $0-30 \mathrm{~m}$ & \multirow{2}{*}{$\begin{array}{c}\text { Downhill } \\
\text { pre-bunching }\end{array}$} \\
\hline & $30-60 \mathrm{~m}$ & \\
\hline
\end{tabular}

STATGRAPHICS statistical package was used for data analysis.

\section{RESULTS AND DISCUSSION}

The research involved 361 trees of fir (Abies alba Mill.), spruce (Picea abies (L.) Karst.), beech (Fagus sylvatica L.) and sycamore maple (Acer pseudoplatanus L.). The damages were recorded on $3.32 \%$ of all inspected trees. The average number of damages per damaged tree was 1.08. One damage was recorded to $91.67 \%$ of damaged trees, and two damages were recorded to $8.33 \%$ of damaged trees.

The share of damaged trees (3.32\%) was compared to the results of other studies. Melemez et al. [33] determined damages to $2.1 \%$ of residual trees in mixed beech-oak stands during animal skidding (by two oxen). Martinić [3] explored damages to residual trees during animal skidding and carrying out (by horses) in thinning operations of young stands, and determined that horse skidding and carrying out cause damages to $1.9 \%$ of residual trees, or to every $52^{\text {nd }}$ tree. Ficklin et al. [23] found that $7 \%$ of residual trees with $>5$ " $(\approx 12.7 \mathrm{~cm})$ diameter at the breast height were damaged by mule-logging system in oak and pine stands (Quercus velutina Lain., Quercus alba L. and Pinus echinata Mill.)

Statistical analysis using $\chi^{2}$ test showed significant difference in the proportion of damaged trees among different pre-bunching methods $(p=0.0008)$. The largest share of damaged trees was recorded during uphill prebunching $(9 \%)$, then pre-bunching on flat terrain (1.58), while during downhill pre-bunching damages to residual trees were not recorded. According to Behjou [34], the probability of damages to residual trees increases with the increase of terrain slope. This ascertainment was confirmed.

Sample plots were divided into two pre-bunching zones with the aim of identifying the pre-bunching distance influence on damage appearance to residual trees. In pre-bunching zone of $0-30 \mathrm{~m} 2.79 \%$ damaged trees were recorded out of all trees belonging to the pre-bunching zone of 0-30 m. In pre-bunching zone of 30-60 m 3.85\% damaged trees were recorded out of the all trees belonging to the pre-bunching zone of $30-60 \mathrm{~m}$. Behjou [34] established that the probability of damages to residual trees decreases as the distance from the skidding trail increases. According to Kulušic [4], the most threatened are trees and regenerations located in the first third of the distance between the skid trail and the transport boundary. The research results did not confirm other authors' findings [4, 34]. Statistical analysis using $\chi^{2}$ test did not show significant difference in proportion of damaged trees between different prebunching zones ( $p=0.5769)$.

Statistical analysis using $\chi^{2}$ test did not show significant difference in proportion of damaged trees among different tree species ( $p=0.4375)$.

Two sample plots ( 3 and 4 ) were located at the distance of $100 \mathrm{~m}$ from the landing on the truck road and another two sample plots ( 1 and 2 ) were located at the distance of $500 \mathrm{~m}$ from the landing on the truck road. The aim of this spatial distribution of sample plots was the identification of skidding frequency influence on damage to residual trees. Trees belonging to the pre-bunching zone of 0-30 m were exclusively analysed. In total 4 damaged trees were recorded on sample plots located farther from the landing on the truck road, or $3.88 \%$ of all trees belonging to sample plots 
TABLE 2. Chi-square test parameters.

\begin{tabular}{lccc}
\hline \multicolumn{1}{c}{ Observed variables } & Chi-square & Df & p-value \\
\hline Pre-bunching method/presence or absence of damages & 14.27 & 2 & 0.008 \\
Pre-bunching zone/presence or absence of damages & 0.31 & 1 & 0.5769 \\
Tree species/presence or absence of damages & 2.72 & 3 & 0.4375 \\
Sample plot position/presence or absence of damages & 1.03 & 1 & 0.31 \\
Diameter at the breast height/presence or absence of damages & 6.44 & 4 & 0.1684 \\
Type of damage/pre-bunching method & 2.44 & 2 & 0.2956 \\
Type of damage/pre-bunching zone & 0.76 & 2 & 0.6835 \\
Damage position/pre-bunching method & 6.24 & 2 & $\mathbf{0 . 0 4 4 2}$ \\
Damage position/pre-bunching zone & 2.27 & 2 & 0.3214 \\
\hline
\end{tabular}

1 and 2 and the pre-bunching zone of 0-30 m. On sample plots located nearer to the landing on the truck road one damaged tree was recorded, or $1.33 \%$ of all trees belonging to sample plots 1 and 2 and the pre-bunching zone of 0-30 m. According to Kulušić [4], the skidding frequency along the tractor road or animal path has an influence to stand damage in such a way that stand damages increase as skidding frequency increases. The research results did not confirm this ascertainment. Statistical analysis using $\chi^{2}$ test did not show significant difference in proportion of damaged trees between the sample plot at different positions ( $p=0.32$ ).

Statistical analysis using $\chi^{2}$ test did not show a significant difference in proportion of damaged trees with different diameter at breast height $(p=0.1684)$. The largest number of damaged trees belongs to the diameter class $5-10 \mathrm{~cm}$, and least to the diameter class $51-80 \mathrm{~cm}$. There were no recorded damaged trees in the diameter class $21-30 \mathrm{~cm}$.

The damages which appeared during wood extraction in previous management periods („old damages”) were

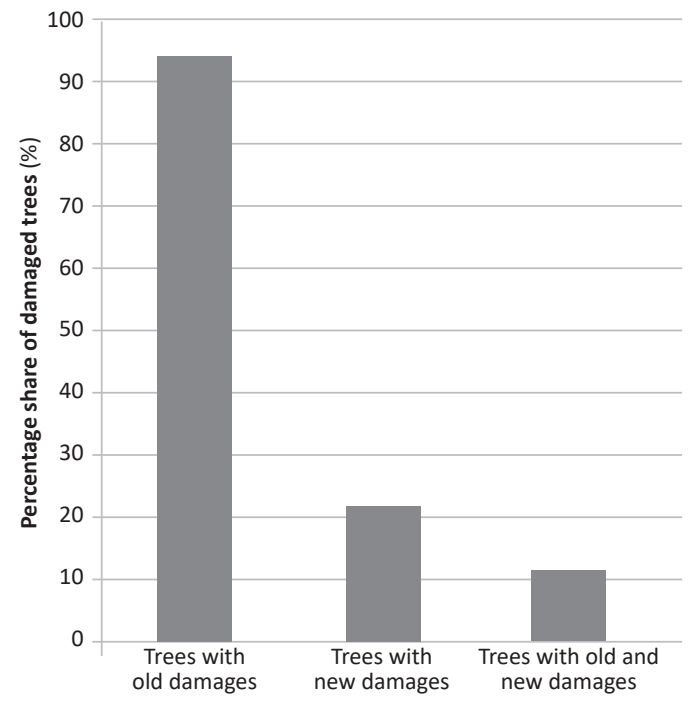

FIGURE 3. The distribution of damaged trees depending on the moment of damage occurrence. recorded on the $9.42 \%$ of all surveyed trees. The presence of old and new damages was recorded on $1.11 \%$ of all surveyed trees, while new damages which appeared during current wood skidding were recorded on $2.21 \%$ of all surveyed trees (Figure 3). It is evident that more damages to residual trees occurred during wood extraction in previous management periods in comparison to current wood extraction in 2017.

The analysis of damages per type of damage showed that the largest percentage share of damages belongs to the category of debarked tree (61.54\% of all recorded damages), followed by squashed bark (23.08\%), and debarked and damaged tree (15.38\%) (Figure 4). Martinić [3] found similar results in a research of felling and animal and tractor skidding during juvenile stands' thinning. The most common type of damage was squashed bark or debarked tree.

Statistical analysis using $\chi^{2}$ test did not show significant difference in the proportion of damaged trees with different type of damage (squashed bark, debarked tree and debarked and damaged tree) between uphill pre-bunching

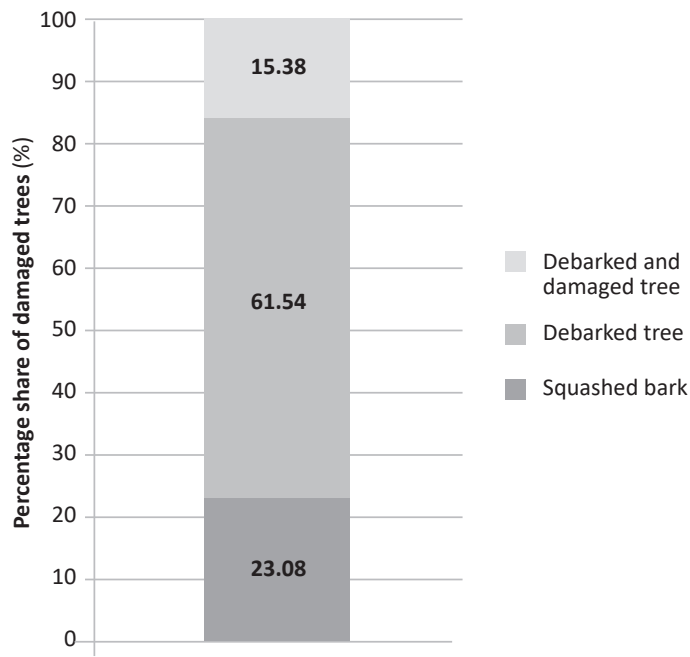

FIGURE 4. The distribution of damages depending on the type of damage. 
and pre-bunching on flat terrain $(p=0.2956)$. Also, statistical analysis using $\chi^{2}$ test did not show significant difference in the proportion of damaged trees with different type of damage (squashed bark, debarked tree and debarked and damaged tree) between two pre-bunching zones $(0-30 \mathrm{~m}$ and $30-60 \mathrm{~m})(\mathrm{p}=0.6835)$.

The analysis of damages per damage position showed that the same number of damages appeared on butt end and root collar (38.46\%). The share of root damages in the total number of damages was $23.08 \%$ (Figure 5). Stem damages were not recorded. The result of research is similar to results of other researches $[1,27,28]$ and showed that damages appear on the most valuable part of the tree. Gurda et al. [28] found that the largest number of damages appeared on the most valuable part of the tree, butt end (at the height bellow $1.3 \mathrm{~m}$ from the ground) during wood skidding with Timberjack 225A skidder. The largest number of damages on residual trees during wood skidding with LKT 81T appeared on the root collar and the lower part of stem, at the height bellow $1 \mathrm{~m}$ [1]. Danilović et al. [27] studied damages to residual trees during skidding with Timberjack $240 \mathrm{C}$ and found that the largest number of damages in the winching phase appear on root collar, and on butt end during the skidding phase.

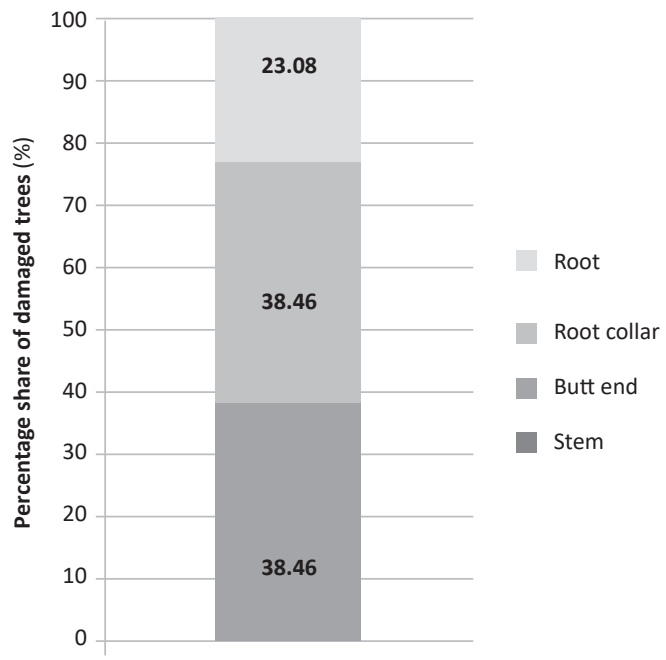

FIGURE 5. The distribution of damages depending on damage position.

Statistical analysis using $\chi^{2}$ test showed significant difference in the proportion of damaged trees with different damage position (stem, butt end, root collar and root) between uphill pre-bunching and pre-bunching on flat terrain $(p=0.0442)$. Root collar damages were exclusively recorded during pre-bunching on flat terrain, while during uphill pre-bunching root damages and butt end damages were also recorded. Statistical analysis using $\chi^{2}$ test did not show significant difference in the proportion of damaged trees with different damage position (stem, butt end, root collar and root) between two pre-bunching zones (0-30 $\mathrm{m}$ and 30-60 m) ( $p=0.3214)$.
Damage size varied between 60 and $570 \mathrm{~cm}^{2}$. The average size of damage was $222.54 \mathrm{~cm}^{2}$ (Figure 6). The results are similar to the results found by Tsioras and Liamas [31], who investigated damages to residual trees during wood skidding with an adapted agricultural tractor (FIATAGRI Model 70.90) and mules in mixed beech and oak stands. The authors found that the largest share in all damages have damages larger than $200 \mathrm{~cm}^{2}$. The determined average size of damage $\left(222.54 \mathrm{~cm}^{2}\right)$ is greater than the average size of damage found by Martinić [3] in the analysis of wood felling and skidding with tractor and animals during juvenile stands' thinning $\left(10-100 \mathrm{~cm}^{2}\right)$.

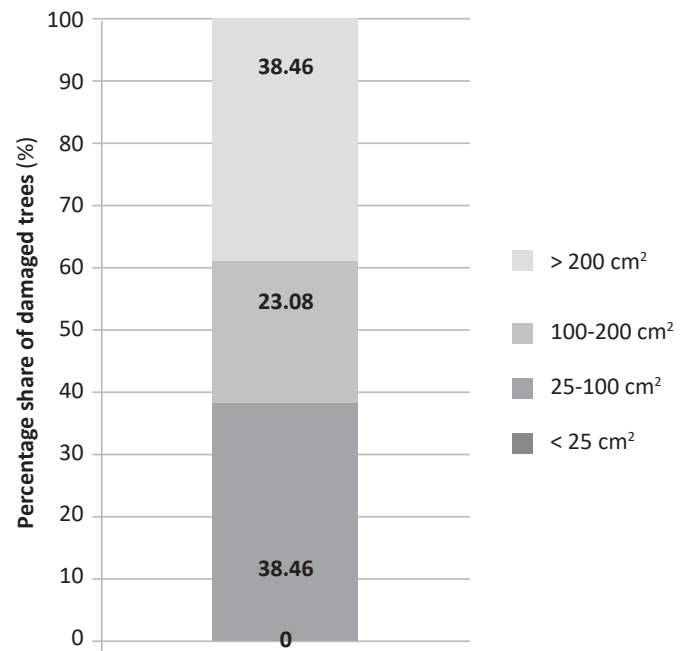

FIGURE 6. The distribution of damages depending on damage size

The average size of damage determined in this research is greater than the average size of damage found in other studies during skidding with a tractor. The average size of damage during skidding with Timberjack $240 \mathrm{C}$ varies between 50 and $200 \mathrm{~cm}^{2}$ [27]. Gurda et al. [28] determined that the dominant damage on residual trees during skidding with Timberjack 225A was debarked tree on the area of $70 \mathrm{~cm}^{2}$ on average. A large number of damages which appeared during tractor winching are caused by winch cable which is why they do not have a large area. During oxen pre-bunching damages are mostly caused by load impact to standing trees. Therefore, damages which appeared during oxen pre-bunching, although fewer of them, on average have greater area.

Damages larger than $200 \mathrm{~cm}^{2}$ were in the largest percentage recorded at debarked and damaged trees (Figure 7). The smallest damages $\left(25-100 \mathrm{~cm}^{2}\right)$ were in the largest percentage recorded at root damages (Figure 8).

Type of damage "debarked tree" was in the largest percentage recorded at root collar and root damages, while "squashed bark" was in the largest share recorded at butt end (Figure 9). 


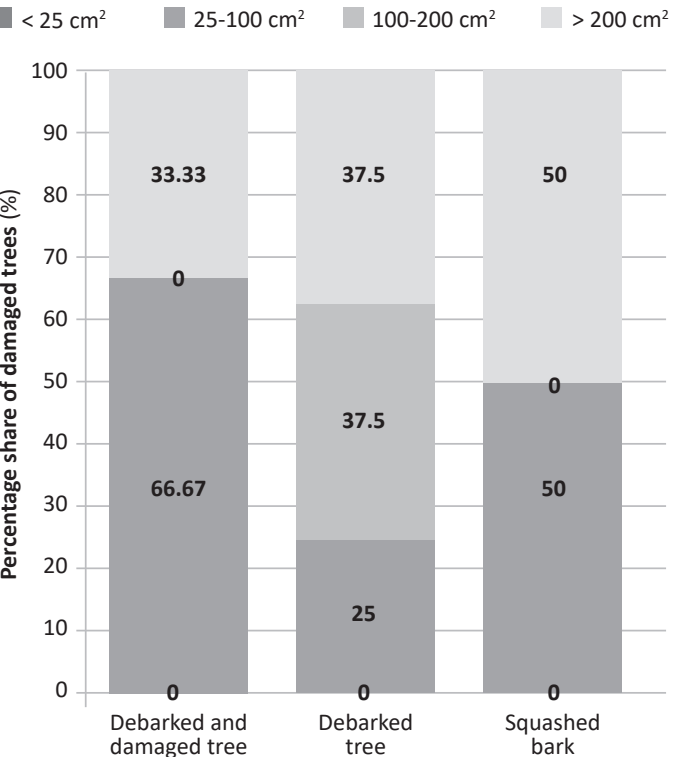

FIGURE 7. The distribution of different size damages depending on the type of damage.

\section{CONCLUSIONS}

It can be concluded that oxen logging causes insignificant damages to residual trees. The result of research showed that damages appear on the most valuable part of the tree, the butt end (at the height bellow $1.3 \mathrm{~m}$ from the ground). The most common type of damage was debarked tree. Damages to residual trees can be reduced by organizational measures and appropriate planning of the felling site with visible marks on terrain, and also by preventive protection of the most threatened trees whose physical protection is done by setting the so-called protectors. In addition to above mentioned methods, the method of "sacrificed tree" is often used in practice. However, adequate control of forest harvesting is most important for high-quality work in forests. More intensive research of damages to residual trees during animal logging is planned to be conducted in the future, as well as the comparison between damages to residual trees during animal and mechanized logging.
$<25 \mathrm{~cm}^{2} \quad 25-100 \mathrm{~cm}^{2} \square 100-200 \mathrm{~cm}^{2} \quad>200 \mathrm{~cm}^{2}$

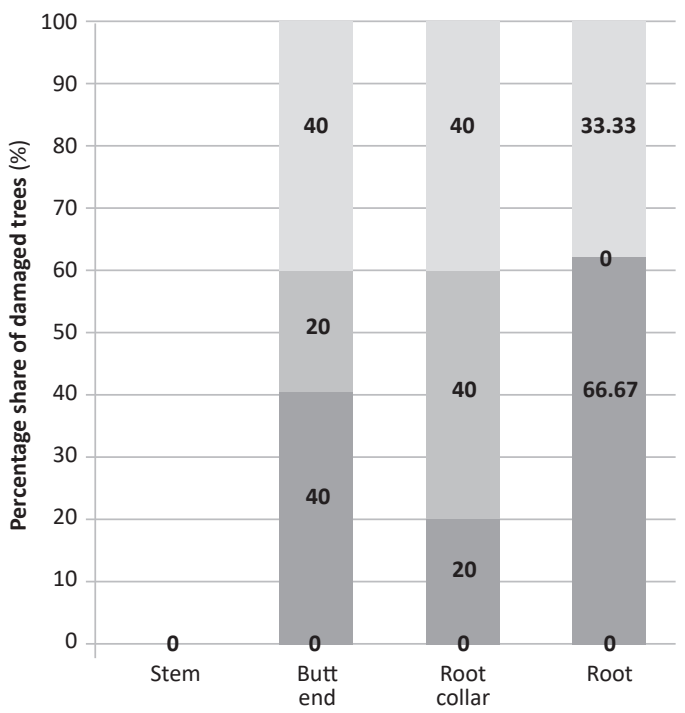

FIGURE 8. The distribution of different size damages depending on the damage position.

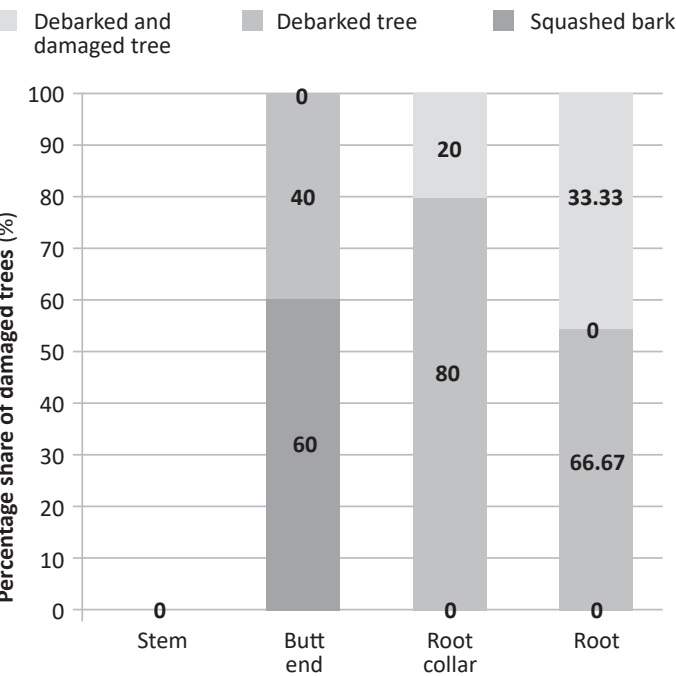

FIGURE 9. The distribution of different types of damages depending on the damage position.

\section{REFERENCES}

1. CUDZIK A 2017 Damage to Soil and Residual Trees Caused by Different Logging Systems Applied to Late Thinning. Croat J For Eng 38 (1): 83-95

2. NAGHDI R, BAGHERI I, LOTFALIAN M, SETODEH B 2009 Rutting and soil displacement caused by $450 \mathrm{C}$ Timber Jack wheeled skidder (Asalem forest northern Iran). J For Sci 55 (4): 177-183
3. MARTINIĆ I 1991 Damage to Stand of Trees in the Felling, Processing and Hauling of Timber (in Croatian with English summary). Sumar list 115 (1-2): 33-48

4. KULUŠIĆ B 2000 Manuscript - Forest Utilization. University of Sarajevo, Faculty of Forestry, Sarajevo, Bosnia and Herzegovina 
5. MARTINIĆ I 2000 ENVIRONMENTALLY FRIENDLY USE OF MACHINERY IN FORESTRY - A SOAP BUBBLE OR A NEAR FUTURE (in Croatian with English summary). Šumar list 124 (1-2): 3-13

6. TAVANKAR F, NIKOOY M, PICCHIO R, BONYAD A, VENANZI R 2017-1 Effects of Logging Wounds on Caucasian Alder Trees (Alnus subcordata C.A. Mey.) in Iranian Caspian Forests. Croat J Fort Eng 38 (1): 73-82

7. ZAHIROVIĆ K, TREŠTIĆ T, MUJEZINOVIĆ O, HASKOVIĆ A 2016 INFLUENCE OF HARVESTING AND EXPORT OF WOOD MASS ON DAMAGE AND HEALTH CONDITION OF FIR AND SPRUCE TREES IN ZVIJEZDA MOUNTAIN AREA (in Bosnian with English summary). Naše šume 15 (44-45): 15-29

8. HALILOVIĆ V, MUSIĆ J, GURDA S, TOPALOVIĆ J 2015 Analysis of the means of forest harvesting in the Federation of Bosnia and Herzegovina. Glasnik Šumarskog fakulteta, Special issue 2015: 55-62. DOI: https://doi.org/10.2298/GSF15S1055H

9. BOJANIN S 1986 The situation on Development and Utilisation of Forests in SR. Croatia (in Croatian). Šumari list $110(7-8): 323-332$

10. ČOMIĆ R 1997 Ergonomy in Forestry. University of Banja Luka, Faculty of Forestry, Banja Luka, Bosnia and Herzegovina

11. MIHAĆ B 1977 Skidding, loading and transport of wood. Works of the Faculty of Forestry and Institute for Forestry in Sarajevo 21 (1-2): 3-63

12. EZZATI S, NAJAFI A, YAGHINI M, HASHEMI AA, BETTINGER P 2015 An optimization model to solve skidding problem in steep slope terrain. J Forest Econ 21 (4): 250-268. DOI: https://doi.org/10.1016/i.jfe.2015.10.001

13. LJUBOJEVIĆ S 2006 PRINCIPLES OF FOREST UTILIZATION IN PROTECTED AREAS AND IN SENSITIVE ECOSYSTEMS. In: Proceedings of Scientific conference: "Management of forest ecosystems in national parks and other protected areas", Jahorina-NP Sutjeska, 5-8 July 2006. Faculty of forestry University of Banja Luka, Banja Luka, Bosnia and Herzegovina, pp 479-484

14. N, SPINELLI R 2011 Integrating Animal and Mechanical Operations in Protected Areas. Croat J Fort Eng 32 (2): 489499

15. GLUSCHKOV S, MARKOFF I, DJAMBASOVA M 2005 Timber haulage with horses in Bulgaria - economical, ecological and social aspects. Forest Sci 41 (1): 73-83

16. MALATINSZKY A, FISCOR C 2016 Frequency and Advantages of Animal-Powered Logging for Timber Harvesting in Hungarian Nature Conservation Areas. Croat J For Eng 37 (2): 279-286

17. BORZ SA, CIOBANU V 2013 Efficiency of motor-manual felling and horse logging in small-scale firewood production. Afr J Agr Res 8 (24): 3126-3135. DOI: https://doi.org/10.5897/ AJAR2013.7306

18. ENACHE A, KÜHMAIER M, VISSER R, STAMPFER K 2016 Forestry operations in the European mountains: a study of current practices and efficiency gaps. Scand J Forest Res 31 (4): 412-427. DOI: https://doi.org/10.1080/02827581.2015. 1130849

19. TOMS CW, DUBOIS MR, BLISS JC, WILHOIT JH, RUMMER RB 2001 A Survey of Animal-Powered Logging in Alabama. South J Appl For 25 (1): 17-24
20. VERANI S, SPERANDIO G 2005 Mechanization in firewood harvesting in southern Italy. Forest@ 2 (2): 233-241. DOI: https://doi.org/10.3832/efor0290-0020233

21. BRAY DB, DURAN E, HERNANDEZ-SALAS H, LUJÁN-ALVAREZ C, OLIVAS-GARCIÁ M, GRIJALVA-MARTÍNEZ I 2016 Back to the Future: The Persistence of Horse Skidding in Large Scale Industrial Community Forest in Chihuahua, Mexico. Forests 7 (11): 283. DOI: https://doi.org/10.3390/f7110283

22. BOJANIN S, KRPAN A 1997 Adjustment of the Skidding Technology to Forest Protection. Sumar list 121(5-6): 243-252

23. FICKLIN RL, DWYER JE, CUTTER BE, DRAPER T 1997 Residual tree damage during selection cuts using two skidding systems in the Missouri Ozarks. In: Proceedings of the 11th Central Hardwood Forest Conference, Columbia, University of Missouri

24. NAGHDI R, LOTFALIAN M, BAGHERI I, JALALI AM 2009 Damages of Skidder and Animal Logging to Forest Soils and Natural Regeneration. Croat J Fort Eng 30 (2): 141-149

25. NAGHDI R, JALALI AM, GHAFFARIYAN MR, LOTFALIAN M 2009 Soil porosity and soil stress for skidder and mule logging sites. Forest Sci 45 (3): 103-113

26. DUDEK T, SOSNOWSKI J 2011 Evaluation of the environmental impact of selected timber extraction technologies used in mountain forests. Sy/wan 155 (6): 413-420

27. DANILOVIĆ M, KOSOVSKI M, GAČIĆ D, STOJNIĆ D, ANTONIĆ S 2015 Damage to residual trees and regeneration during felling and timber extraction in mixed and pure beech stands. Sumar list 139 (5-6): 253-262

28. GURDA S, MUSIĆ J, SOKOLOVIĆ DŽ, BAŠIĆ M 2016 Damage on standing trees during wood skidding (winching phase) by cable skidder Timberjack 225 A. Works of the Faculty of Forestry University of Sarajevo 46 (1): 74-87

29. PORŠINSKY T, OŽURA M 2006 Damage to standing trees in timber forwarding. Nova mehanizacija šumarstva 27 (1): 4148

30. TAVANKAR F, BONYAD AE, NIKOOY M, PICCHIO R, VENANZI R, CALIENNO L 2017 Damages to soil and tree species by cableskidding in Caspian forests of Iran. Forest Syst 26 (1): e009. DOI: https://doi.org/10.5424/fs/2017261-09100

31. TSIORAS PA, LIAMAS DK 2010 Hauling damages in a mixed beech oak stand. In: Proceedings of $43^{\text {th }}$ International Symposium on Forestry Mechanisation: Forest engineering: Meeting the Needs of the Society and the Environment, Padova, Italy, 11-14 July 2010

32. MENG W 1978 Baumverletzungen durch Transportvorgänge bei der Holzernte - Ausmaß und Verteilung, Folgeschäden am Holz und Versuch ihrer Bewertung. Schriftenreihe der LFV Baden-Württemberg 53: 159

33. MELEMEZ K, TUNAY M, EMIR T 2012 Investigation of some Extraction methods in Terms of Damages on Forest Stand. In: Pentek T, Poršinsky T, Šporčić M (eds) Forest Engineering - Concern, Knowledge and Accountability in Today's Environment, Proceedings of 45th International Symposium on Forestry Mechanization, Dubrovnik, Croatia, 8-12 October 2012. Forestry Faculty of University Zagreb, Zagreb, Croatia

34. BEHJOU FK 2014 Effects of Wheeled Cable Skidding on Residual Trees in Selective Logging in Caspian Forests. SmallScale For 13 (3): 367-376. DOI: https://doi.org/10.1007/ $\underline{\text { s11842-013-9259-x }}$ 